\title{
The Biopolitical Conditions of Sovereign Performativity
}

\author{
Benjamin Taylor
}

This article explores the relationship between sovereignty as an ontologically ineliminable capacity possessed by all existent beings and biopolitics understood as a regime of material distribution that constitutes some lives as worthy to be lived while disallowing others to the point of death. Sovereignty and biopolitics are thus fundamentally related, though at differing levels of analysis. Biopolitics concerns a structural regime of distribution, a regime produced by countless practices of individual spatial mastery. The link between sovereignty and biopolitics is consequently one of practice, not of abstract logics. In a market society, the self-valorization of capital of necessity dialectically produces accumulation of wealth not merely in the abstract but in concrete material manifestations of space. "Ghettoized" and "citadelized" spaces logically derive from the biopolitical nomos that conditions how sovereignty is enacted in late modernity. Sovereignty never disappears, but the milieu within which it is expressed is constantly shifting as the emergent outcome of collective practices of spatial mastery change.

Sovereignty thus only exists "in a fluid state, in motion" because in "every positive understanding of what [it is] exists a simultaneous recognition of its negation, its inevitable destruction” (Marx 1977 [1873]: 103). In the strictest sense of the term, then, political sovereignty can never fully secure itself because any form of rule is transient, partial, incomplete, and open to contestation and transformation. The contemporary import of the concept of "sovereignty" is derived from Christian theology, in which God's sovereignty was indicated by nothing other than his own absolute power. Early theologians interrogated the scope of this power, debating whether God was to be considered bound by the laws of nature that he himself had issued or was able to undo or interrupt those laws as he saw fit. To what extent, theologians inquired, was it necessary for God to intervene in the world that he had created with an "exception" to the normal order of things?[1]

The division is between God's power as potestas ordinata and as potestas absoluta: the former bound by what God had already ordained, the latter totally unbound (Elshtain 2008: 21). Could God, for example, "raise up a virgin after she has fallen," or did the laws that he had previously set in motion constrain him, preventing him from acting as he would wish? (Ibid, quoting St. Jerome).[2]

The only limitation to the range of potential authority, though, was God's own authority. In the scope of human affairs, his power was effectively wholly unbounded. As the God of the Bible proclaimed to Job: "Where were you when I laid the foundations of the Earth? / Tell Me, if you have understanding. / Who determined its measurements? / ... To what were its foundations fastened?" (Job 38: 4-6, New King James Version). Power alone functioned as the basis for God's right, to be expressed finally at the end of days, to judge the nations. Thus, in Revelation, Jesus returns to Earth in order that he may purify it: "Now out of His mouth goes a sharp sword, that with it He should strike the nations. And He Himself will rule them with a rod of iron. He Himself treads the winepress of the fierceness and wrath of Almighty God. And He has on His robe and on His thigh a name written: KINGS OF KINGS AND LORD OF LORDS” (Rev. 19:15-16, NKJV). This final image of Jesus ought to remind us of Jesus's grant of authority to Peter, taken by the Catholic Church to be identical with the inauguration of the papal office, in which Jesus says, "I will give you the keys of the kingdom of heaven, and whatever you bind on earth will be bound in heaven, and whatever you loose on earth will be loosed in heaven" (Math. 16:19, NKJV). 
Understood in these initial theological terms, God's sovereign right to act was bounded by nothing other than the limits of his own capacities, and these capacities were, more or less, absolute. The transfer into politics, on the other hand, included this pretension to absolute authority without the corresponding capability to enforce it. As, for example, Hobbes's Leviathan (1968 [1651]) makes clear, individuals are a perpetual site of instability because of their lust for power, and the absolute authority of the Sovereign to act to constrain them is, ultimately, the only thing that guarantees sovereignty's perpetuity. The absence of sovereignty would result in nothing other than a relapse to the precedent state of nature: "And though of so unlimited a Power, men may fancy many evill consequences, yet the consequences of the want of it, which is perpetuall warre of every man against his neighbor, are much worse" (Hobbes 1968 [1651]: 260 [II.xx]). When I say that "sovereignty does not exist," I thus mean, as the history of Western political theories' attempts to secure it has demonstrated, that sovereignty as a state or subject's ability wholly to order the world in accordance with its authoritative intentions can never reach the Godlike level that would totally eliminate the possibility of dissent. The absolute authorship that is central to the concept of sovereignty is always partial and incomplete when introduced into politics, which are unavoidably rooted in a destabilizing multiplicity.

However — and with so broad a claim, the "however" is what really matters — the theorized absolute mastery of God over the whole of creation is reflected to a certain degree by the ways in which all manner of existent beings act to master and appropriate their own space. From the most quotidian practices to the grandest schemes for utopian organization, the appropriation of spatiality is where any and all attempts to become sovereign must originate, even as the ongoing mastery of space is the clearest hypostatization of the ideal form of sovereignty. To understand how sovereignty is performed in the world of experience rather than theorized in the world of theology, we will have to explore individual practices of sovereignty, which together make up collective regimes of distribution that temper the forms of agency that sovereign actors can express. This includes exploring how the concept of "biopolitics" fits with the concept of "sovereignty." Many attempts have been made to reconcile the two terms as they appeared in Foucault's thought. My argument is specifically a rebuttal to Giorgio Agamben's "topological" spatiology of sovereignty, which is insufficiently attentive to the historical regimes of distribution that create spaces not of exceptionality but of normal (and normalized) indigence. By dematerializing biopolitics in the "logics of sovereignty," Agamben misses the ways that specific enactments of sovereignty as practices of spatial mastery are enabled by and justify biopolitical regimes of distribution. I instead return to Foucault's account of the biopolitical as a discrete historical-political dispositif, the operations of which are immediately material, even as they operate according to an imaginary of optimization. "Biopolitics" produces spatial relations that accord in an ever-moving relation to and dialectical tension with representations of space. As certain forms of life are made to live and others are "disallowed to the point of death," the range of imaginable practices open to fostered forms of life expands. Disallowed forms of life come to appear as "bare" even as they yet retain sovereignty — and as the range of potentially actionable practices may become increasingly narrowed. Representations of "bare life" and "sovereignty" in practice disguise the fundamentally potentially bare quality of all life: its ontological precariousness.

I begin with a critique of Agamben's (1998 [1995]) analysis of the relationship between sovereignty and biopolitics, showing how it is both internally incoherent and less useful than Foucault's (1990 [1976]) original account of biopolitics. Next, I turn to Henri Lefebvre's (1991 [1974]) tripartite model of spatial practices, representations of space, and representational space in order to begin to grasp the variety of practices made possible through, and themselves making possible, biopolitical regimes of distribution. The production of space, Lefebvre helps us to see, is a never-ending activity. Individually and collectively, we are perpetually engaged in relations of spatial production and representation, which function together to bring new worlds into being. These practices must be undertaken at the level of the body, even as individual bodies alone cannot contain the effects of these practices. From Lefebvre I turn to Carl Schmitt (2006 [1950]), who argues that the production of space is a constantly contested and not merely benign practice. To produce space is simultaneously to limit the ways that others can produce space. These contestations in space and over space are the sites of struggles out of which some are able to simulate their (ontic) self-sovereignty, while others are left in a situation of socially induced "precarity." [3] I then explore recent sociological literature regarding the distribution of space in contemporary U.S. cities, paying special attention to citadelization and ghettoization as dialectically intertwined ongoing spatial practices that simultaneously function on the register of representation in evident and meaningful ways. Finally, I argue these intentionally manufactured displays of precarity and the concomitant reality of material abundance for some help to disguise the ontological precariousness that characterizes all being. This relationship between sovereignty and biopolitics is fundamentally opposed to the version offered by Agamben because it privileges relations, practices, and representations over abstract logics. 


\section{Agamben's Account of Sovereignty and Bare Life}

Giorgio Agamben opens his Homo Sacer with the claim that Foucault never clearly explicated the "hidden point of intersection" between "techniques of individualization and totalizing procedures," which Agamben equates with the sovereign and biopolitical "models of power" (1998 [1995]: 6). It is not entirely clear which of these techniques corresponds with which model of power as disciplinary power, which for Foucault is the mode of power concerned with individualization, goes unmentioned. Nevertheless, this allegation of lack permits Agamben to assert that the Foucauldian thesis "will then have to be corrected, or, at least completed" (Ibid: 9). Agamben's attempt at a correction comes through the distinction between zoē and bios. Zoē indicates life in general, whereas bios is the form of life made possible in community. Zoē is also the condition of possibility of bios insofar as communal life first requires that life exists at all, but according to Agamben, zoē is only (representationally) included within bios to the extent that it is excluded from it in the form of homo sacer, the figure who can be killed but cannot be sacrificed (Ibid: 82); the "fundamental activity of sovereign power is the production of bare life as originary political element and as threshold of articulation between nature and culture, zoē and bios" (Ibid: 181). The distinction between zoē and bios parallels the relationship between voice and language. Just as the human being is the "living being who has language," it is the zoè that is also capable of bios (Ibid: 7-8). The founding act of sovereignty, according to Agamben, is the exclusion of zoē from the polis, which is functionally equivalent to the creation of zoē within bios via the sovereign ban and internal exclusion of homo sacer.[4] Because sovereign power constitutes itself in relation to "bare life," he reasons, the politics of sovereignty has been biopolitical from the very beginning.

At times Agamben's account seems as if it is merely an analysis of the fundamental contradictions in the law's assertion of a durable and concrete relationship to life. In order for the law to be effective, it must presume itself to grasp in a real way the forms of life over which it ostensibly has control. It must "create the sphere of its own reference in real life and make that reference regular" (Ibid: 26). But since the law cannot be so precisely constructed in advance that it covers every conceivable exigency, there must remain within the law a way for the law to deal with the unexpected, or else the structure of the law falls immediately into disarray. The law must presume the state of exception. The state of exception is a state where the law is in force, yet every act (or at least every act enacted by the Sovereign) maintains the force of law, meaning that no act falls outside of the law: "[T]he sovereign power is this very impossibility of distinguishing between outside and inside, [state of] nature and [state of] exception, physis and nomos" (Ibid: 37). Thus, when Agamben says that the "exception everywhere becomes the rule," he does not mean "exception" in the sense of a constant negation of the norm but instead as a "realm of bare life" in which the distinctions on which law is founded become unintelligible (Ibid: 9). In such a space, the Sovereign can no longer act unlawfully because the Sovereign's actions are coterminous with the law. The camp thus comes to function as the "nomos of the planet" precisely because by functioning as a space in which "power confronts nothing but pure life, without any mediation," it represents in its everyday operations a site where no action can be lawful precisely because no action can be unlawful (Ibid: 176, 171).

François Debrix (2015) reminds us that for Agamben the space of the camp is not merely topographical, i.e., it is not merely a specific location that functions as an example of the furthest extent of biopolitical logics, but topological as well. It is the logical possibility that life and law might in any space become indistinct. Debrix writes,

What matters for Agamben (and what eventually may allow one to pose topographical questions such as those listed above) are the relations and redistributions of power and violence that the space of the camp both reflects and enables. The camp, for Agamben, occupies a place in biopolitical designs, in and for political power, because it operates as a topological matrix that potentially connects bodies in space to a range of operations of force, control, exception, or utility. This is what it means for Agamben to declare that the camp is an "absolute biopolitical space" (2015: 447).

The distinction here between "topology" and "topography" is a helpful one because it seems to apply not only to the state of exception (and also nature) but likewise to the figure of homo sacer. While the exclusive inclusion (i.e., the ban) of homo sacer from the political order is the "originary" act of sovereignty, the figure of homo sacer plays a primarily illustrative role in the course of Agamben's argument, demonstrating a topographical instance in which the capability of the sovereign to decide on the exception appears; the historical homo sacer is a topographical instantiation of the Sovereign's alleged topological capacity to declare some lives as bare. Thus, the Sovereign and homo sacer occupy the "two extreme limits" of the juridical order, each simultaneously inside and outside of it: "the sovereign is the one with respect to whom all men are potentially homines sacri, and homo sacer is the one with respect to whom all men act as sovereigns" (Agamben 1998 [1995]: 84). 
Agamben's affixation of "potentially" to the power of the Sovereign makes the concreteness of the condition of homines sacri all the more apparent. If the sovereign is recognizable because he potentially decides on the exception, homo sacer is can only be recognized if it is being actively treated in an exceptional manner. Sovereignty is the site of all potentiality (the potential to declare another homo sacer), while homo sacer is the site of all impotentiality (one has not merely been declared but is being made homo sacer). The Sovereign is a specific figure (thus "he" rather than "it"), recognizable not because he actually declares the exception but because the Sovereign cannot exist without the possibility of exceptionality, exceptionality in potentiality. Conversely, the concrete reality of homo sacer is that all are "sovereign" with respect to it because being cast outside the law's protection means it can be killed at any time without ramification. Homo sacer is not merely the figure who can be killed but not sacrificed but, in more general terms, one "who can be deliberately killed without [the killer] committing homicide" (Minca 2006: 387).

Agamben argues that the Hobbesian state of nature is a state of exception, one that is "is not so much a war of all against all as, more precisely, a condition in which everyone is bare life and a homo sacer for everyone else" (1998 [1995]:106). This, however, throws something of a a wrench in Agamben's apparent denial of virtuality to homo sacer. If it is possible to imagine a condition in which each is concretely homo sacer, then that same condition is necessarily one in which all others are simultaneously concretely sovereign in relation to homo sacer. But if it is possible for each to be concretely sovereign and homo sacer with respect to all others, then it is also topologically or virtually possible that the positions of sovereign and homo sacer can be swapped. A topological matrix of relations of power reflects nothing other than the abstracted form of potentially concrete relations. "Virtually" thus takes the sense of "potentially concrete," even as concrete manifestations reveal what was previously only (but which also remains presently) a virtual possibility. A virtual possibility passes into a virtual impossibility only once that which once could have been concrete can no longer possibly manifest itself. The virtual existence of either pole of the sovereign-homo sacer dyad requires the virtual existence of the other, even as the same holds with respect to the concrete manifestation of either pole. The relationship is always and only dialectical. The state of nature is thus the space of the permanent and indistinct virtuality of each subject as both sovereign and homo sacer with respect to all others, which further implies that to be constituted as homo sacer is to be in the presence of an actively subordinating, and not merely legally declaring, sovereign, even as the potential to be sovereign is only realized in the concrete creation of homo sacer or homines sacri. Sovereignty and homo sacer are thus topologically stable positions that permit immanent judgments with respect to topographical relations as they concretely obtain. However, these relations are not topographically stable. Who is acting as sovereign and who is being made homo sacer depends on concrete relations.

Rather than being left with a complex topology, we instead find a complex topography represented in a relatively simple topology.[5] Actual topographical "spaces of exception," the indistinction of life and law, occur at each juncture where sovereignty is constituted through not merely the declaration that another is homo sacer but instead the concrete production of another as homo sacer. No killing can be de facto murder because every killing constitutes a real space of exceptionality, and exceptionality authorizes every act as lawful. In what other sense could the state of nature have contained real homines sacri? Sovereignty as "ban" is not yet possible in the state of nature. The topological relationship between homines sacri and sovereigns cannot recognize murder, not because killing homo sacer is less than murder and killing the sovereign is more than murder, as Agamben claims, but because the category "murder" is law's post facto appellation onto a material encounter that exceeds the law's ability to capture it factually. As such, when Agamben emphasizes that Hobbes's solution to how the state of nature is transformed into civil society is that each lays down the right to engage in sovereign and homo sacer-producing actions that each may lawfully undertake in the state of nature, it is unclear what exactly this "laying down" could mean. It makes no topological sense unless it has somehow become wholly impossible for the weakest to kill the strongest. Otherwise, each is always both potentially homo sacer and sovereign in relation to every other. For a topological relationship to obtain, it must correspond to possible concrete realities as their abstract matrical form. In the case of laying down the possibility for sovereignty, it would necessarily require the absolute impotentiality of non-sovereign subjects (i.e., those who have laid down their right to sovereignty and become always and only bare life) ever to constitute The Sovereign as homo sacer - through killing him, for example — and themselves as sovereign in return. Hobbes is not unaware of this. Establishing a political order does not alter the fundamental topology that obtains whenever there are multiple subjects: each is always already virtually sovereign and virtually homo sacer in relation to all others. The weakest can always kill the strongest.[6]

The topographical appearance of a Sovereign and specific homines sacri is consequently a bit of political 
obfuscation. The Sovereign persists solely as the mythology of absolute sovereign potentiality capable of declaring the absolute impotentiality of other forms of life. The collective agreement by some sovereign homines sacri in an historically specific context to treat one individual as their ruler and to refer to this ruler as "the Sovereign" does nothing to alter the fundamental topological relationship that Agamben's account does reveal. However, this means that Agamben's analysis of the "logics of sovereignty" tells us nothing more about politics or its structure than does the bleak Hobbesian assertion repeated above because topo-logics only enable us to understand abstractions that are of necessity actually rooted in real-world practice. Every understanding of the world is, as we will see most clearly through Lefebvre, in some sense theoretical. But this does not imply that every theoretical account of collective life usefully illuminates the complexity in which we are perpetually embedded. Topological representations are inevitable, but they are a way of making topography understandable, not of discovering the previously hidden basis of all political activity — the "hidden point of intersection" that Foucault ostensibly missed. As William Connolly puts it, "Biocultural life exceeds any textbook logic because of the nonlogical character of its materiality. It is more messy, layered, and complex than any logical analysis can capture. ... [] t corresponds entirely to no design, no simple causal pattern, no simple set of paradoxes" (2007: 31). Indeed, the relationship between the capacity for sovereignty and its actual manifestations is itself complex. It depends on "biopolitics" not merely as the bare life produced as the originary act of sovereignty, as a topological structure, but as biopolitics expressed in the distinct topographical material-spatial actualities it engenders and prevents.

\section{Foucault's Biopolitics and Their Relation to Sovereign Power}

Why, though, return to the concept "biopolitics"? There is no incantatory power to its phonetic or graphic form and no salvation to be found by returning specifically to the Foucauldian oeuvre. Indeed, the term seems to play a relatively minor role in the range of Foucault's writings, and it would perhaps not be too difficult to construct the narrative that follows without turning to Foucault. Nevertheless, I believe there are compelling reasons to do so. I have two. First, the concept of biopolitics indicates much more than simply the concern of politics with life, even as Agamben and those of his ilk tend to reduce it to a fully symbolic or logical relationship between some idea of life and some practice called politics. [7] One aim of my return to biopolitics in the context of sovereignty is to correct this "correction" to Foucault's hypothesis. Second, and beyond this somewhat reactive justification, the language of biopolitics helps to emphasize that politics, especially the politics of distribution, is unavoidably about making a series of decisions regarding who will live and who will die. Some forms of life will be made to live. Some will be disallowed to the point of death. On this matter, Agamben is wholly correct. There seems to me to be an immediately tactical and polemical benefit to using the term "biopolitics," and perhaps even a term such as homo sacer, albeit in a modified sense that keeps in mind the concrete and dispersed ways in which lives are fostered or neglected. This benefit is located in the specifically and originally Foucauldian sense of the term, which thus requires some preliminary exegetical work.

Let us move a bit closer, then, to a direct analysis of actual regimes of making live and letting die, leaving behind the sanctified and sanctimonious ground of the purest topologies and their rarefied airs. The first question to pose is, "What does Foucault mean by 'biopower' and 'biopolitics?" In his published works, the first use of these terms comes at the end of History of Sexuality, Volume One: The Will to Knowledge (1990 [1976]). The characterization Foucault offers, at which I have gestured multiple times already, is that the "ancient right to take life or let live was replace by a power to foster life or disallow it to the point of death" (Ibid: 138).[8] This shift is definable only in its social, which is to say material, manifestations. Foucault is concerned to note that he is interested not in a "history of mentalities" but in "a 'history of bodies' and the manner in which what is most material and most vital in them has been invested" (Ibid: 152). In this account, a scientized "analytics of sexuality" permits the emergence of a whole series of technologies by which populations are increased, strengthened, and made capable of waging war on behalf of an idealized image of themselves. The objects to which this form of power — which "dovetail[s] into [disciplinary power], integrate[s] it, modif[ies] it to some extent, and above all, use[s] it by sort of infiltrating it, embedding itself in existing disciplinary techniques," albeit it "at a different level, on a different scale, and ... mak[ing] use of very different instruments" (Foucault 2003 [1997]: 242) — addresses itself to "the ratio of births to deaths, the rate of reproduction, the fertility of a population, and so on" (Ibid: 243). These are the objects that eventually make it possible for various techniques of government to conceive of humanity as a "species" and as a "population." 
The final chapter of The Will to Knowledge overlaps significantly with the last lecture provided during Foucault's series of January to March 1976. A wholly different path precedes the earlier analysis, though. Rather than preoccupying himself with the issues of sex and sexuality, he instead examines the route by which it became possible to think of society as a war, to believe that "peace itself is a coded war" (Ibid: 51). According to this image of society, certain elements of the social body pose a potential risk to its continued vitality, and thus precautions must be made against them. They must be managed, relegated to the pale, subjugated in manifold ways. Foucault is essentially tracing the emergence of non-biological accounts of race that permit the "biologizing state racisms" of Stalinism and Nazism to emerge. The link between this account and the narrative in The Will to Knowledge is that the techniques of managing sexuality are inextricably intertwined with the health of the population as a "race." Those conceived as belonging to "lesser" racial elements could not be permitted to put at risk the population as a whole. The "whole politics of settlement, family, marriage, education, social hierarchization, and property ... received their color and their justification from the mythical concern with protecting the purity of the blood and ensuring the triumph of the race" (Foucault 1990 [1976]): 149. What in The Will to Knowledge begins as a concern for the aristocratic body (symbolics of blood) is thereby shown to be a concern for the aristocratic body in distinction to the body of the undesirable elements of society, which only becomes more pronounced in the sexual sciences of the bourgeois.

What we see, then, is a fundamentally different understanding of "biopolitics" in Foucault than in Agamben. For Foucault, biopolitics is a historically specific form of governmentality, a technology of power whose history he traces back to the emergence of "pastoral power" in Christian medieval society. Foucault might agree, then, with Agamben that there is something similar between the inclusive exclusion of homo sacer within the juridical order and later forms of power that discriminate between and amongst members of the political order. Yet to the extent that "sovereignty" is, for Foucault, the form of power that actively kills, the legally exclusionary activity that produces homo sacer cannot be an act of sovereignty, even if it proceeds from the figure who is legally determined to be Sovereign. Put differently, in a biopolitical regime, the law is one of many active mechanisms by which social hierarchies are materially maintained. The relationship of the sovereign ban is a complex one, in which it is never quite possible to say whether the power of the sovereign is still in force or is wholly absent. Biopolitical power, on the other hand, is marked by its active maintenance of these divisions by forms of policing that run throughout the social. Each life is made to live in its own way, which in turn corresponds with a certain representation of the material-spatial politics at play for any given life. It is perhaps no coincidence, then, that Foucault's lecture series The Birth of Biopolitics, held from January to April 1978, ended up focusing entirely on neoliberalism and liberalism as a governing rationality that constantly poses the question of whether one is governing too much, of what the proper field of government is (Foucault 2008 [2004]: 317-324).[9]

Foucault's account provides a better framework for understanding the relationship between sovereign potentiality and its actual social expression — the relationship between sovereignty and biopolitics — than does Agamben's, even as Agamben understands himself to be developing precisely this element of Foucault's thought. Sovereignty as the ontologically inalienable freedom to act in accordance with the capacities of one's mode of being, the pure form of sovereignty transmitted from theology into politics, is limited on the ontic plane by technologies of power that distribute material and representational potentiality in ways that make some modes of being more conceivable than others and other modes less so. The question then becomes exactly how these representations and practices function together in order to enable the fullest range of ideational potentiality for subjects who are always already sovereign, who are always already (potentially) freer than they feel themselves to be. "Biopolitics" in this context refers to the production of spatial-material lifeworlds that allow different imaginaries of sovereign potential to be conceivable. To stay at the level of sovereignty's logics, as Agamben does in Homo Sacer, is to pretend that mere abstractions are sufficient for providing an account of the social world and its politics.[10] The concreteness of Foucault's arguments, especially in contradistinction to Agamben's, reminds us how much more complex and varied the world of experience is, which in turn highlights how necessary it is to focus on the materiality of politics, which takes the form of space's mastery, appropriation, and production.

\section{The Embodied Production of Space}

From Agamben and Foucault, we are left with two competing accounts of sovereignty. For Agamben, it is a 
specific topological structure that manifests itself concretely, while for Foucault, it is a specific historical juridicallegal regime characterized by "letting live" and "making die." The theological version of sovereignty with which this chapter began offers a third alternative, in which "sovereignty" is a term that means something like "agency": the ability of God to act as limited only by the extent of that ability. This third definition is the one I now want to consider. Agamben's version, as we have seen, is somewhat useless. Foucault's is historically useful, but it does too much to bracket sovereign agency and its relationship to biopolitical regimes of distribution. No matter how totalizing a regime of power is, there always remains the possibility for its distuption through disobedient action. Attempts to achieve political sovereignty on the model of God's authority may always be thwarted, even if immense exertion would be required to do so. Consequently, drawing from these theological debates from late antiquity at the level of the subject rather than the state does more to reveal the relationship between individual subjects' appropriations of space and the general regimes of distribution that result from them.[11]

Obviously, though, sovereignty in this sense can never reach the sweeping heights contained in God's absolute creative authority. Nevertheless, it does have a creative element, concerning itself with both practices and logics, i.e., with material extensions or with novel interpretations. Both elements must be simultaneously present. Material extension requires the possibility of the interpretation that movement has occurred, while to think the external world is to think a world of extensions. One produces a sign in space by judging or interpreting that one has acted to produce a sign in space, which requires an assertion regarding what counts as a sign. "[A]ll subduing and becoming master involves a fresh interpretation, an adaptation through which any previous 'meaning' and 'purpose' are necessarily obscured or even obliterated," as Nietzsche puts it (1989 [1887]: 77 [II.12]). The relationship between materiality and interpretation pervades the totality of language as a representational system, which is language as far as it is langue. Everything only is itself for us if it is also the sign of itself.[12] We need not presume that our representational system is exhaustive with respect to some sort of "world-in-itself," but everything that we are capable of acknowledging as existing must be capable of representing itself as itself to us.

The questions that are crucial to ask here in order to discern the specific social conditions that limit this theological form of sovereignty's material expressions for specific subjects are consequently twofold: how is "space" socially produced, and what is the specific social production of space that maps onto the desire for security that attempts to actualize sovereign potentiality in the world of experience? For the first of these questions, Henri Lefebvre's The Production of Space (1991 [1974]) is a most insightful source. Lefebvre thinks about the production of space through the grid of "spatial practices," "representations of space," and "representational space," terms that correspond to a "concrete (as distinct from the 'immediate')" triad describing space as it is perceived-conceived-lived (Lefebvre 1991 [1974]: 40). The first of these terms, spatial practices, is somewhat tautological insofar as all practices occur in space and all spatial events must in some sense be practiced. Nevertheless, it would be foolish to provide an account of how space is produced without first acknowledging action in space. This is the site of the "mundane facts of the human condition, in particular the experiential unity of our bodies" (Caraccioli 2011: 98).[13] Representations of space refer to the ways in which space is abstractly conceived. This is "the space of scientists, planners, urbanists, technocratic subdividers and social engineers ... all of whom identify what is lived and what is perceived with what is conceived" (Lefebvre 1991 [1974]: 38). Space here is systematically abstracted as a uniform system imposed onto space as a grid of legibility. Finally, representational space is "space as directly lived through its associated images and symbols ... but also [the space] of some artists and perhaps of those, such as a few writers and philosophers, who describe and aspire to do no more than describe" (Ibid: 39). While these elements of spatial production are logically distinguishable, in practice, they cannot but interpenetrate one another. Space is simultaneously lived (spatial practice) and understood (representational space) in its immediate manifestation only in relation to the abstract and systematic topology (representations of space) within which it is embedded. Put a bit more obscurely, space is never empty but is instead constantly engaged in the practice of thinking and producing itself.

This model is relevant to the project being undertaken here. Lefebvre's terms permit us to distinguish analytically what are in actuality simultaneous and inextricable elements because social being in the world as an intensely embodied encounter. Sovereignty as it manifests in the world of experience must take place at the level of the body. Correspondently, how the body is practiced in order to master social space is itself a manifestation of sovereignty. Accounts that are attuned to the body's centrality to social and political practice consequently better position us to examine how sovereignty is expressed in the mastery of space.

Judith Butler and William Connolly provide us with two of the best accounts of how politics are practiced at the level of the body. In Gender Trouble (2006 [1990/1999]), Butler offers a reading of gender rooted in the Nietzschean belief that "'the doer' is merely a fiction added to the deed — the deed is everything" (Nietzsche 1989 
[1887]: 45 [I.13]). That there is no doer behind the deed means that the logic of how space and identity are organized cannot be found in a yet-to-be-discovered arcanum that could link together how we perform our bodies with who we consider ourselves to be.[14] In other words, practices by bodies determined to be "male" or "female" do not neatly correspond to the gender identity categories of "man" and "woman." In the contemporary age, this seems hardly a radical claim. Butler, however, goes a step further in arguing that the very division between "primary sex characteristics" is rooted in the performativity of gender. Because male and female bodies have been disciplined and trained to perform themselves in masculine and feminine ways, the importance of primary sex characteristics as both a source of sexual pleasure and as a determining characteristic for how that body ought to be performed is reinforced. The division between male and female only registers as important if there is some sort of performative, which for being performative is not any less concrete, division that can be erected to constitute these biological lines. The performativity of gender, itself a "stylized repetition of the body," thus creates the mythology of its own interiority as a secondary effect of its ongoing performance. The fiction of the essence of gender follows performances of gender. "Gender," Butler writes, "is the repeated stylization of the body, a set of repeated acts within a highly rigid regulatory frame that congeal over time to produce the appearance of substance, of a natural sort of being" (Butler 2006 [1990/1999]: 45).

Butler's analysis intimately ties together the how the body is performed and the desires that it manifests. To prefer one series of pleasures over another depends to some significant extent on the narrative or symbolic regime within which they are made recognizable as pleasures, even as recognizability is inextricable from the bodily performances that are undertaken. William Connolly picks up on this theme in the context of his work on the affective dimensions of fascism. Connolly reads the materiality of the body in a variety of contexts, including 14th- to 16th-century European table manners, professional dancing, the film Fifty Shades of Gray, German military training, and his own upbringing in Michigan, which included learning and participating in modes of bodily performance patterned by figures such as football players and male adults in his neighborhood (2017: 44-58). Affect for Connolly is everpresent in these accounts. It is necessarily material. What else could it be? "Our gaits, hormonal secretions, rhythms of conduct, tacit rules of eye contact, facial habits of expression, skin dilation or tightening, memory layered modes of perception, and relational presumptions convey such disciplines into habitual modes of response," he writes (Ibid: 47). Connolly is specifically concerned with the bodily performances that open some subjects to fascist political projects. When the body is practiced and understood in certain ways, it potentially opens subjects up to abduction by such imaginaries: an ideal of masculinity may require constant willingness to prove one's toughness, to stockpile weapons for protecting one's family from all and any potential adversaries, or support for a juridical-legal formation that prioritizes force and activity over negotiation and contemplation. These practices, and the political regimes they support, appeal not merely to intellects but to bodies as practiced and representational objects. It is little surprise that the bodies Connolly focuses on are those of the "armored male." Gender, it seems, it one of the most crucial perceived-conceived-lived regimes available.

From Connolly and Butler, we can come to understand the importance of bodily practices in the world as primary to all politics and all representations of space. Importantly, though, there can be no "stylized repetition of the body" without a representational imaginary that links together distinct, disparate acts under a common term. The same Nietzsche who observed that there is no doer behind the deed also made a case against the existence of "identical actions." Because we are always-already in a world of becoming typified by ontological fluctuation, the "I" that is at each moment confronted with its own existence is a wholly different bodily practice than the "I" I perceive myself to have been only moments prior, and I am linked together as a subject only by an interpretive and representational series of regulations that permits me to conceive of myself as one and the same subject (Nietzsche 1989 [1886] 25-27 [I.19]). This is the difficulty that lay at the root of the classical origin of the dialectic; we are alwaysalready not what we are (Kolakowski 1981 [1976]: 11-12). Even to ask the question of how this distinction between "being" and "becoming" might be somewhat resolved, though, failed (and still fails) to acknowledge that the roots of subjectivity must be found historically in the development of the regulative fiction of the "I," a regulative fiction whose origin Nietzsche locates in the violent mnemonics used to cultivate subjects capable of promising.[15] Thus, the representation of ourselves to ourselves, the formation of an Ideal-I as this regulative fiction, must precondition, embed, flow through, regulate, and discipline our spatial practices. The way that we occupy and consequently master space is dependent on the specific way we interpret what we are doing, and vice-versa.

Lefebvre includes an illustration that helps to illuminate the centrality of bodily performativity to the production of space, and thus to politics more generally. He provides us with the picture of a house. It stands before us, seemingly stable, seemingly unmoving. A closer look, though, shows that the existence of this house is not static, it 
does not stand unchanging permanently within the confines of being. Rather, it is engaged in a networked series of relations that constantly alter its "actual" spatial composition. It is "permeated from every direction by streams of energy which run in and out of it by every imaginable route: water, gas, electricity, telephone lines, radio and television signals, and so on" (Lefebvre 1991 [1974]: 93). Perhaps yellowjackets or termites are burrowing into some of its wood. Perhaps a particularly heavy foot repeatedly ascending the stairs has weakened the boards. Wind and rain beat down upon it; electricity and people, gas and bugs flow in and out. We ought not to see the house as a static entity, writes Lefebvre, but instead as the intersection of a series of inflows and outflows that always threaten to disrupt the border of where the house ends and the external world begins: a series of flows in which we are intimately involved. It is an "active body," an "information-based machine with low energy requirements" (Ibid). The being of the house is a sympoietic "being with" rather than an autoefficient "being-in-itself," even as the reified "representational space which its inhabitants have in their minds ... for all its inaccuracy plays an integral role in social practice" (Ibid).[16] That these flows compose a house is consequently a matter of historically situated judgment, tempered in part by the fact that certain of these processes at present exceed our active, as opposed to reflective, perceptive capabilities. It is possible to imagine a cybernetic subjectivity that would overlay onto our perception of the house all of these biomaterial flows. Perhaps what would then constitute the space of a "room" or a "wall" would shift, dependent for its definition on the degree to which the flows in and out of it are relatively limited or (im)permeable. The point, though, is that the claim that the house is a house is not absolute but is rather a representational judgment of external space projected onto a networked set of spatial practices that have been composed otherwise in the past and may yet be composed otherwise in the future.

At each moment, then, we are engaged in spatial practices, but whether these practices rise to a level of social legibility for us depends on whether and to what extent they correspond to or potentially disrupt the collective representations of space in which we are embedded. The gesture of a finger may be unimportant when it is connected to a lifted hand spinning lazily through the air. The same fingeration may be of greater importance if the digitudal gesture "flips off" the president (Dvorak 2018). It is also here that we see the sense in which embodied subjects are subjectified before they are even individuals, as Althusser (2001 [1970]) observes.[17] It becomes (for some) accidentally humorous when an infant raises its middle finger on its own precisely because the spatial practice accords to a specific symbolics of space in which the infant is embedded before it even becomes aware of its own subjectivity. The body is thus disciplined before it has even become confronted in any unified sort of way with its own existence. It is engaged in spatial practices that are already representational, even if the body engaged in the spatial practices in incapable of recognizing them. Further, it reproduces those representations through ongoing bodily practices: decorating a house, steeling oneself to fight, preparing food for dinner, working long and late hours, etc. These practices are, or have been in the past, representationally coded as either male or female acts that specific bodies repeat in stylized ways, even as some sort of representational schema is first required to acknowledge the repetitions as repetitions. Only space as representationally presented is legible as something other than either nothing or too-much-something. For space to be legible, it is necessary that everything always be only the sign of itself.

\section{Practices of Sovereign Space}

This passage through Lefebvre, Butler, and Connolly articulates the logics of spatial practice in a way that is attuned to the social, historical, and ideational forces that anchor a perspective on space as an ongoing process of embodied mastery rather than as no more than a philosophical abstraction acknowledging the possibility of material extension. Likewise, their arguments permit us to move from an account of theological sovereignty expressed as nothing other than a subject's pure potential for authorship in the world to an understanding of how such authorship is actually carried out, limited as it is by the world's multiplicity. Lefebvre's account of representational space intertwines with the Butlerian account of gender as a fictive uniformity, of which Connolly's "armored males" are one expression, to emphasize how social symbolics emerge out of spatial practice. Carl Schmitt provides us with yet another crucial element for thinking about space with his emphasis on the Greek term nomos (2006 [1950]). Nomos, according to Schmitt, derives from the Greek nemein, which means "to divide" and "to pasture." From this, Schmitt contends that "nomos is the immediate form in which the political and social order of a people becomes spatially visible — the initial measure and division of pasture-land, i.e., the land-appropriation as well as the concrete order contained in it and following from it" (Schmitt 2006 [1950]: 69-70). No political order is thus possible without this original act of appropriating space; it forms the basis of the later processes of distribution and 
production (Ibid: 327). More than mere mastery of space (spatial practices), nomos articulates the "spatially concrete unity" of "measure, order, and form," the "concrete order contained in [land-appropriation] and following from it" (Ibid: 70). As such, every nomos requires the initial appropriation of land, but "not every land-appropriation, not every alteration of borders ... is a process that constitutes a new nomos" (Ibid: 82). While the appropriation of space has historically extended to the sea and to the sky, it is specifically the division of land that is foundational to the nomos. It is the case "[n]ot only logically, but also historically, [that] land-appropriation precedes the order that follows from it" (Ibid: 48). Whereas the sea cannot be partitioned through permanent spatial barriers, the land can, which means that the land can be internally and externally divided for the purposes of political communion. A variety of "fences, enclosures, boundaries, walls, houses, and other constructs" delimit the land that belongs to a particular people from both the peoples and lands that are not theirs (Ibid: 42). Appropriating land is thus simultaneously a representational and a practical act. To say "this is mine" or "this is ours" presupposes a relationship to the "this" that cannot ultimately be reinforced through legal structures alone but which requires actual or implied practices of violence.

Those appropriations of space that do not seek to create a new nomos (constitutive power) are consequently engaged in the process of preserving it (constituted power). What we know from Lefebvre is that there is no moment that is not in some way related to the constituted or constitutive mode of power. Whether spatial practices are seen as constitutive or as embedded in a prior constituted regime is thus a question of the representational space and spatial representation within which a subject's actions are embedded. We can take Schmitt's account of the distinction between the possibility of a political order rooted in the sea and a political order based on the land as demonstration the importance of the representation of stability. According to Schmitt, the sea could not even logically serve as the basis for a nomos because it lacks the appropriating structures that maintain the divisions between a political order and what is not a political order. But the divisional structures that appear terrestrially are not in and of themselves the basis for a continued political nomos. The basis for this nomos is the representational (in both senses) role that the walls play with respect to the way that a people orders itself. The ostensibly obdurate material blockades that clearly divide inside from outside and prevent the outside from invading the inside must be perpetually maintained in order to be effective, and whether they are perpetually maintained depends upon the desire for their continued maintenance. When the Berlin Wall was brought down, it was felled by sledgehammers, hands, and heavy machinery. Were these tools unavailable prior to 1989 ? Certainly not. What shifted instead was, for numerous complex historical reasons, the will to continue practicing politics in a way that maintained the wall: shooting at any who came too close or tried to cross, staffing it with guards, repairing its erosions, etc.

A recent This American Life episode on walls makes the same point in the contemporary era through the tale of David, a Cameroonian man, who attempts to break into a Spanish city of Ceuta, located in Morocco (Glass 2018). [18] If he arrives in the city, he might apply for asylum and travel to Europe. Surrounding the city is a fence towering twenty feet high and adorned with razor wire, complete with a two-meter trench in front of it and guards behind it. The fence that keeps "non-Europeans" outside of the "European" space could easily be cut by wire-cutters, but the reporter for the segment relays an unspoken agreement that those attempting to cross will not use such tools. Similarly, the Spanish guards on the other side use rubber (rather than real) bullets, so those attempting to enter refrain from using weapons in their quest. The city sits on the shore, and the fence ends when it reaches the water. Those trying to cross the fence and enter into Europe have developed a whole range of tactics by which the guards might be distracted or overwhelmed, thereby allowing some refugees to reach the local immigration center and potentially claim asylum. The whole enterprise is transformed into a giant game with real-world stakes immanent in the encounter, perhaps thereby demonstrating the "game-iness" that is always inherent to politics. David eventually defeats the wall and goes to live in Madrid, where, as of the story's broadcast, he still lives. He defeats the wall largely because the guards opt to take him to the immigration office after he has finally traversed the wall rather than to throw him back out on the other side. The wall is only effective as long as the guards are there, as long as a whole societal organization (we might say the nomos of Ceuta, and perhaps of Europe) is made possible by the rejection of the African/Middle Eastern/Asian outside.

Walls collapse or can be made to collapse. At sea, opposing vessels may either attack you or choose not to attack you. At no point is the "order" of the world ever permanent or fully stable. Rather, it is stable to the extent that a particular series of spatial practices can be judged to accord relatively durably with a specific image of space, an image that must be daily renewed through the ongoing practices of real-world subjects in its defense. When the tyrannical order at the end of $\mathrm{V}$ for Vendetta (McTeigue 2005) breaks down, it breaks down not because Parliament is destroyed. It breaks down because the men with guns who had previously been willing to shoot and 
kill insurrectionist citizens have become unwilling to do so. They have come to imagine themselves and the general citizenry differently. The spatial imaginary in which they participated has altered in a way that makes their spatial practices incapable of being maintained. Conversely, when Ponchel, a French solider, is shot by Jonathan, an Irish solider, at the end of Joyeux Noël (Carion 2005), a film set during World War I, Jonathan is only able to pull the trigger because his spatial-political imaginary has not been altered by the Christmas Eve mass in which soldiers from all sides have joined. (Ponchel is dressed as a German, and Jonathan believes him to be one.) While other soldiers have difficulty continuing to fight because they no longer imagine the soldiers in the trench across from them as enemies, Jonathan, mourning, enraged, and embittered by the death of his brother, still practices himself under the auspices of an imaginary that constitutes all humans on the opposing side as enemy soldiers deserving of death. A specific place-history-identity nexus functions together to permit layers of symbolic meaning to be overlain on the bodies that populate the battlefield; a series of ideological practices intervene between man and man.

Ultimately, the maintenance of a relationship between practices in space and any given spatial representation must be actively renewed at each moment by those committed to it. Spatial practices of sovereignty are a commitment to a specific ordering of the world, an ordering that is only possible because the practices that constitute it and the spatial imaginary that interprets those practices occur simultaneously and in an ongoing fashion. The nomos of a given social ordering does not flow necessarily from the initial appropriation. The initial appropriation is stretched, stressed, and remade in an ongoing process that (re)shapes the spatial-material being of the participants in a certain way of life. The order is daily reconstituted. Practices in space always participate in constitutive power because the potentiality of the world is at every moment exhausted. Whether the nomos of a particular order can be said to have changed depends entirely on whether the spatial representations that legibilize certain practices remain tenable, which indeed does require the sort of decision-making that acknowledges an exception to what has come before though it is never the Sovereign who alone makes such a decision.

\section{Biopolitical Sovereignties}

We are now prepared to address the set of relationships that obtain between practices of political sovereignty and biopolitical regimes of distribution, examining them through the nexus of uneven spatial accumulation in the contemporary U.S. city. I choose the contemporary U.S. city as the site of empirical observation for a series of reasons. First, cities occupy an important position in the contemporary imaginary of social scientists. From world cities to global cities to resilient cities, understanding "the urban" grows in importance as the world moves toward ever-increasing urbanization (Rogers 2016 [2012]; Sassen 2000; Sassen 2016; Friedmann 1986). Second, in U.S. politics, cities occupy an important representational space worthy of further interrogation. Conservatives, for example, point to them as a space of extreme criminality that demonstrates the allegedly failed attempts of slightly more redistributive economic policies. For the Democratic Party, cities are typically bastions of support, which only increases the urban-rural tensions that have received much commentary since the 2016 presidential election. Most importantly for my purposes, though, they are a site in which life that could reasonably be presented as "bare" or "disallowed" according to a biopolitical logic nevertheless acts to produce its own space in a variety of important ways.[19]

Cities, of course, do not exist in and of themselves. Spatially speaking, the sense in which they exist at all is a matter of representation. Cleveland is as distinct from a farm as it is from New York City, yet the heuristic of "city" links together Cleveland and New York while excluding the farm. Likewise, the existence of city spaces is only made possible through non-city spaces that help to sustain cities as dense population centers. I acknowledge these also important relations of space in order to bracket them. In this study, my focus will be on the distribution of space in the U.S. city.[20] Consequently, the next portion of this article briefly reviews some of the relevant sociological literature that broadly characterizes the specific patterns of spatial-material distribution occurring in the contemporary city. Abundance and poverty are generated as part of the same process. Drawing from Carl Schmitt, we might say that the broad typologies to be discussed are distributional regimes integral to the reproduction of the city nomos. The Lefebvrian observation that constituted power is also always constitutive power also helps to illuminate that distribution is necessarily founded on appropriation in the sense that every distributive moment is an appropriative moment (the mastery of space inherent to all spatial practices), even if not every appropriative moment is also distributive (though since "distribution" as a bequeathing from one to another effectively requires 
the recipient to appropriate the materialities being distributed, the relationship is perhaps not so clean in practice). After exploring this literature, I discuss the ways in which a specific spatial nomos of appropriation-distributionproduction as enacted and legibilized by a lived-perceived-conceived veridical regime enables subjects to simulate their own sovereignty through the reification of space, as well as briefly discussing some of the affective drives that motivate this series of undertakings. How do individuals take active and constant control over their space through a variety of spatial practices? How are some potential forms of life promoted and others disallowed? What are the limited and partial ways in which the ontologically ineliminable potential for subjects $\backslash$ existents to author themselves and their lifeworlds is expressed in the material world?

Peter Marcuse, sociologist and son of Herbert Marcuse, examines the forms of spatial organization that have resulted in racially and financially segregated cities in a way that begins to move us toward an answer to such questions. In a 1997 article, he introduced a typology of various spatial formations that could then be found in the "post-Fordist" city: the "outcast ghetto," the "classic ghetto," "enclaves, and "citadels." The concept of the "citadel" comes from John Friedmann and Goetz Wolff, where it is a minor theme in a much longer article: "[T] he world city may be divided ... into the 'citadel and the 'ghetto.' Its geography is typically one of inequality and class domination. The citadel serves the specific needs of the transnational elites and their immediate retinues who rule the city's economic life, the ghetto is adapted to the circumstances of the permanent underclass" (1982: 325). Other scholars have described the relationship between "the ghetto" and "the citadel" as dialectical; the citadel requires the ghetto in order to remain comprehensibly exclusive, even as the ghetto results from resources being directed toward and secured within citadel spaces (Smithsimon 2010: 702).[21] Citadels are spaces where the wealthy can keep themselves away from contact with "poorer and lower status people." Indeed, citadels' very design, whether in the form of a gated community or a guarded high rise, is to keep poor people from intruding on the daily patterns of behavior in which the wealthy participate. Marcuse writes, "Outer doors controlled by closed-circuit television cameras, doormen who double as security personnel, controlled egress from elevators, and combination locks on entry to underground garage space serve to protect residents" (Marcuse 1997: 247). A specific series of spatial practices clearly reproduces the division between those who belong "inside" the citadel and those who should stay "outside." The practice is consequently only made possible through an imaginary of what counts as worthy of belonging to the citadel space.

Such an imaginary, though, depends on a clear conception of what does not belong within the site of agglomerated wealth, which is in turn enabled through the clear consignment of certain otherized bodies to the spaces to which they are representationally understood to belong. Marcuse develops the importance in the United States context of the emergence of "a new ghetto that is different from the ghettos of the past and from the immigrant enclaves of the past and present" (Ibid: 229). These "new" ghettos, which were emerging in the immediately post-Fordist period Marcuse was then studying, resulted from the historically and culturally unique combination of "space and race" in U.S. cities, wherein the aftermath of slavery, Jim Crow, and redlining combined to segregate black Americans in ways that both corresponded with and reformulated a long legacy of exclusionary spatial practices.[22] Loïc Wacquant (2012) supplements Marcuse's analysis by constructing an ideal-type model from the "four constituent elements of the ghetto," namely, stigma, constraint, spatial confinement, and institutional parallelism. He contends that the ghetto "is a social-organizational device that employs space to reconcile two antinomic functions: (1) to maximize the material profits extracted out of a category deemed defiled and defiling, and (2) to minimize intimate contact with its members so as to avert the threat of symbolic corrosion and contagion they are believed to carry" (Wacquant 2012: 7). On Wacquant's account, then, the otherization of those who are eventually ghettoized both precedes their spatial cordoning off and is intensified through the processes of spatial segregation that are inaugurated. Representational space and spatial practices are intertwined at every moment, and certain specific spatial practices (i.e., racialized representations enacted by single bodies) have effects that quite literally extend into space generally. This is selfevidently true for the emergence of the ghettoization of the black Americans who are the primary residents of the specific spaces Marcuse and Wacquant analyze (since both Marcuse and Wacquant aim to analyze segregated spaces); black bodies were stigmatized long before black subjects were spatially separated in cities from the "normal" white population. Of course, this initial stigmatization was itself only made possible through specific material-spatial regimes: segregated schools, enslavement on plantations, the denial of political and civil liberties, and so forth.

More recently, Marcuse has moved away in some respects from his position in 1997, contending that the "hard ghetto" (ghettoization as the result of legal policy) has been replaced by a "weak ghetto," in which social forces such as "the operations of the private market in housing" (including both direct racism and income inequality) are what lead to the spatial conglomeration of marginalized groups (2012: 40). Ghettoization, he contends, is now being "despatialized" in order to satisfy demands for urban space on the part of affluent city residents, i.e., due to gentrification 
(Ibid: 54-57). Such processes may appear to eliminate some of the forms of spatial control that have typified the ghetto classically, but as Marcuse notes, de-spatialization of once-concentrated oppression does not indicate that the oppression itself has decreased. Rather, the problems may "have just been moved around, not solved" (Ibid: 60). Indeed, as a recent report in The Atlantic notes, in cities such as Chicago, "the number of wealthy census tracts has grown fourfold since 1970" (Semuel 2018). Chicago, Alana Semuel reports, has not seen wealth "cree[p] back into some poor neighborhoods" because many Chicago residents have classist and racist "mental maps" of the city, representations of space that identify certain places "they would never live, no matter how affordable the rents or good the amenities” (Ibid). Semuel interviewed Harvard sociologist Robert J. Sampson, who attributed the difference between Chicago and other cities that have been engaged in gentrification to Chicago's racial segregation. "As middleclass residents stay out of such neighborhoods, so do the businesses that they would patronize," summarizes Semuel. "The decades-old legacies of segregation, far from being reversed, are instead being reinforced" (Ibid).

The citadel and the ghetto are consequently self-enforcing divisions of space. In Schmitt's sense, we might be justified in asserting that these sociologists are attempting to identify the specific nomos that holds for American urbanization. Nomos need not only apply globally, even as Schmitt's concern is with the specific form of the global nomos. Nomos indicates first and foremost the form of land appropriation that permits a specific regime of distribution and production to follow from it. Wealthy Americans who reside in urban citadels appropriate the space in a legible, ongoing manner, an appropriation that implies (and in fact produces) ghetto spaces that are its opposite. It would be a mistake, though, to see ghettoized spaces merely as the passive implication of a broader distributive and productive scheme that follows directly from this initial appropriation. Impoverished spaces are appropriated as well, albeit in ways that differ significantly from the mode of appropriation in the citadels.

Contemporary forms of ghettoization in the United States, which take the form of the marketization of relationships initially grounded in direct racism, function to constitute a population that can then be disallowed to the point of death. While some of the criteria for segregation may have predated the actual practices of segregation, segregation simultaneously functions to clarify or reconstitute the population of disallowable lives. Anathematized bodies are those who live in the ghetto because the ghetto is the place for anathematized bodies. The Euthyphronic divisions between a "carried thing" and a "thing that is carried" break down in the dialectical manifestation dialectical in that segregation follows from the divisions in space it has already generated — of a presumably always already ontologically negatable form of life. The ghettoizable form of life is thus a form of life that belongs to the ghetto, which is the identification that constantly haunts black bodies as they move throughout the world. Elijah Anderson (2012a; 2012b) picks up on this theme, examining the ways that black bodies are read as alien in spaces that do not align with the dominant white imaginary:

\begin{abstract}
Although black people increasingly inhabit diverse positions in society, negative stereotypes persist and adapt to changing social situations. For instance, the ghetto stereotype follows middle-class black families into the suburbs. Some whites eye their new neighbors warily because they are not used to living near black people, perhaps thinking of them as "nice black people" who are exceptions to their race, or suspecting they have not arrived through legitimate means. Could they be drug kingpins? How else to explain a black man who drives a new Lexus and sends his children to private school? (Anderson 2012a: 17).
\end{abstract}

Though it was the original pathologization of blackness that justified its consignation to a separate location, the process of consignation continues to mark the body as "other" in ways that justify both its continual containment, conceptually and spatially, as well as the rescinding of all programs aimed at assisting the fostering of life in materially "other" spaces.

Consequently, when Wacquant writes that the "ghetto arises through the double assignation of category to territory and territory to category," he is indicating that the intellectual and/or material confinement of a specific race (which has been preliminarily "otherized" in ways that permit it to be disallowed to the point of death) within a specific place consequently underpins the spatially inegalitarian distribution of resources along lines that correspond to the presumed race of the subjects dwelling in specific locations (Wacquant 2012: 13). Spatial segregation is one manifestation of inegalitarian distributions according to which black lives are "disallowed," and the living spaces open to black Americans play significant roles in determining their vocational, educational, and other life options. When Anderson details the many spaces in which black bodies are not welcome, it is because black bodies are identified with particular spaces (ghettos) that they are viewed as alien in alternate spaces (non-ghettos). There is a nexus between space and identity, between spatial practices (tacit or explicit arts of discrimination, including ways of looking and speaking), representational space (the identification of a black person as black, with all the 
attendant symbolic implications that result from such a judgment on the basis of America's racist past and present), and representations of space (an abstracted vision that projects where specific bodies belong on the basis of the characteristics they are determined to have). These elements are irreducibly different yet inextricable from each other. All forms of unequal treatment require otherization, and otherization is always expressed spatially.[23]

Elsewhere, Anderson has observed that those who live in the inner city (to be clear, not just those who are black) are often employed in jobs for which those with lower levels of education are competing, jobs such as janitors, office cleaners, fast-food workers, office assistants. Of these, "[m]ost of the available jobs pay little and provide few if any benefits" (Anderson 2012b: 71).[24] Further, such workers are "often the first causalities in an economic downturn" (Ibid). As such, the increased precarity of labor in the United States as well as the "recent drastic reductions in welfare payments" cause many inner-city residents (in practice belonging to all races, though perhaps not representationally so) to turn to "informal economies," which are accompanied by a host of social practices aimed at ensuring the integrity of agreements that cannot be supported through conventional legal channels and which may force residents to resort to violence, including killing, in order to make certain that future agreements are not similarly breached (Ibid: 70-72). Whether or not the perpetrators of such acts are primarily black, the acts become representationally linked with the spaces in which black bodies are presumed naturally to reside. Consequently, because ghettoized blackness, which according to Anderson functions as the representationally dominant form of blackness in white imaginations, becomes linked to such practices of violence, the state-sponsored distributional practices that permit an influx of funds into ghettoized economies can be stayed, which in turn intensifies ongoing processes of ghettoization. Residents of racially-economically segregated spaces do not comport with a vision of the optimization of the population as a whole, so they can be "disallowed to the point of death." Because "race" and "place" become coterminous, the distribution of resources away from specific populations, which is always carried out on a spatial register, can be carried out.

What these sociological observations help to demonstrate more clearly is that the collective production of space typical of a capitalist economy necessarily expresses itself in the form of spaces of relative immiseration and spaces of relative opulence. The accumulation of capital requires the dialectical opposition of the circuit M-C-M' and its implied opposite of something like $\mathrm{M}^{\prime}-\mathrm{C}-\mathrm{M}$, where $\mathrm{M}$ is the relative value of total assets in relation to the total output of the economy and M' is a larger value than M. As the proletariat invests its sole "asset," its living labor power, to produce commodities and is then remunerated for producing those commodities, the remuneration must be sufficient for social reproduction yet, taking the perspective of the global economy as a whole, not at a rate that permits labor to repurchase the same proportion of commodities it has already produced. If the latter condition were the case, then capital could not perpetually increase, and there would be no motivation for investors to engage in new investment schemes as their total wealth would at best stay the same (if the investment were successful), at worst decline (if an investment fails and is a loss to them). Capitalists will consequently always look for new sites of investment yielding a positive return, i.e., the ability to purchase a higher percentage of all available commodities than was previously possible before investment. The ability to purchase more commodities includes the ability to purchase a home or multiple homes in highly segregated (by class and race) spaces, while the correspondent inability to do likewise includes a decrease in one's ability to afford living spaces in neighborhoods of average or above-average price. The question of "Whose value is rising?" is consequently always also a question of "Whose space is being ghettoized?" and "Whose space is being citadelized?"

Because this dialectical process relatively immiserates some while preserving and advancing the position of others, decisions must be made regarding who will be made to flourish and whose lives will be disallowed to the point of death. In the United States, the way this determination is made follows from the country's racist history and thus manifests itself along racial lines. Importantly, though, to justify the decision to let some lives flourish while disallowing others, a division between lives worthy and unworthy of life must be made. A capitalist distribution of resources consequently always requires some sort of relatively stable representational divide between "good" lives and "bad" lives. Capitalism is always-already biopolitical, and in some (many) historical periods, the dividing line of distribution is race.[25]

To view a population as potentially disposable is both a feature of the actual material allocations made with respect to such a population as well as the representational construction of it. Life disallowed to the point of death is first marked as disposable in the very act of "disallowing" in the sense that the material abundance of society is oriented away from a specific people group. In the contemporary transnational character of the economy, these distributions are both the result of wealth polarization derived from the precarity of manufacturing labor in the United States and domestic policy decisions that actively remove support systems from beneath the feet of inner-city 
residents. The right-wing myth of a close nexus between "hard work" and affluence performs the same justificatory function. Those who are poor have "chosen" to be poor, whether directly through prodigality or indirectly through imprudent financial decisions. The spatial representation that abstractly envisions the outcomes of a marketoriented economy as the most just, beneficial result intersects with representational space (the space of perception) to code individually impoverished subjects as positioned in relation to that overall matrix, thereby justifying (if not mandating) a certain set of bodily practices in relation to them (perhaps glancing off to side as a homeless veteran asks for change or clutching one's bag tighter while walking past a group of young black males).

\section{Sovereign Performativities and Ontological Precariousness}

What is the relevance of this sociological analysis of the biopolitical distribution of material flourishing to an examination of the ways that sovereignty is performed and practiced in the world of experience? Sovereignty, as I have presented it here, is the capacity of an existent to act in accordance with the potentiality of its being, a potentiality that includes, in Agamben's (1999 [1993]) terms, the ability to-do-or-not-to-do. Because of the inescapability of social multiplicity, this form of sovereignty can only ever function as an ideal, an ontological abstraction that must be presumptively possible in order for the idea of action in the world to be legible. This is the theological model of "sovereignty as authorship." However, sovereignty as authorship is, as we have seen, always incomplete because authoring is always an intersubjective encounter. It depends on readers as much as writers. [26]

Nevertheless, the desire for something like sovereignty still remains. The empty, tautological form of the desire for sovereignty in conditions of multiplicity is the desire to act as one desires to act within one's capacity for action. But how can such a desire be achievable? One must be able to imagine oneself as free, as bound only by the attachments one gives to oneself.[27] In a complex society, this includes safety from the vicissitudes of fortuna. The subject working to achieve sovereignty is the subject of The Prince's penultimate chapter, working to channel the raging river of fate such that it might not overflow into the basement of the newest McMansion. While this project may reflect a fundamentally individualistic desire, the politics of it are not thereby necessarily individualistic. Indeed, spatial practices, which are necessarily collective, produce the uneven spaces of accumulation typical of a capitalist economy, especially a capitalist city. The wealthy assemble increasingly in "citadels," while the poor of all races congregate in their "ghettos." Biopolitical distributional regimes are the emergent outcomes of collective spatial practices undertaken in accordance with representational experiences linked together by the abstract representations of space that function as norms of recognizability for actual practices in space.

If sovereignty is, abstractly, the capacity of an existent to act in accordance with its form of being, then the ongoing appropriation of space in which all spatial practices engage are manifestations of sovereign potentiality as limited by the fundamental condition of multiplicity that characterizes being in the world. Space is never empty; it is always part of an existent subject. Biopolitical regimes of distribution emerge from this appropriation of space and support its continuation. Whether state distribution policy accords with a social democratic or broadly Keynesian logic that, generally speaking, reflects the will of the working population or is neoliberalized on behalf of the capitalist class, it is part of a tactics of space appropriation that reflect the possibility of sovereignty as it appears in the world. Whereas for Agamben the link between biopolitics and sovereignty is one of logics, the link here is one of practice. The ability to appropriate space, which includes the space occupied by another's body, manifests collectively in the distributional shifts that can be examined at a structural level in the historically specific regime of distribution that functions under the label of "biopolitics." Even as it has structurally distinguishable effects — which we might legitimately call its nomos,[28] not as an arcanum but as a distinguishable pattern or collection of patterns made legible through a specific representational regime — such appropriation has its existence only in practice. It begins in practice, at every moment is carried out in practice, and produces the world from which later practices must proceed. These practices are ontic manifestations of the ontological capacity for sovereignty.

"Citadel" is a well-chosen term in that it implies an attempt to protect oneself from that which is without. What is the "outside" against which the wealthy must erect barriers? It is the concretely representational space of the ghetto, which ever knocks at the door of the citadel. If the wealthy are uncareful, the ghetto's residents might revolt and expropriate the citadel dwellers. Even worse, citadel dwellers might suddenly find themselves impecunious and on their way to a ghettoized space. The fear, in short, is that the citadel dweller might be declared by the market to be homo sacer, to be outside the economic-political order that permits social flourishing to occur and consequently to 
be permanently at risk of experiencing violence. Poverty and wealth, we have seen, must not merely be produced but maintained through the ongoing practices that master space in a specific way. The divide between rich and poor must be "policed" in the broadest sense of the term. In ghettoized spaces, this often involves encountering "the police" as an institution authorized to use lethal force against enemies of the law, and to the extent that poverty is always an enemy of the law of the bourgeois, all those who are ghettoized or who representationally correspond to the ideal of what members of ghettoized spaces ought to look like are legitimate potential targets of institutionalized police.

None of these ontically concrete practices in constant pursuit of the ideal of sovereignty fundamentally alter either the potentiality of an existent to act in the world or the ontologically precarious quality of all existence, i.e., its finality. The pursuit of sovereignty is the desire for "power after power ceasing only in death" that Hobbes identifies, which derives not merely from the effect of natural "fancies" inherent to specific beings but from buying into the discursive regimes, simulations, and ideologies that constantly produce insecurity. Property rights, the police, systems of surveillance, moral-ethical doctrines, and so forth mediate and limit the capacity of beings to act in the world in the ways necessary to reproduce and transform their own existence, construing some as homines sacri while permitting others to appear to themselves as Sovereign.

In this context, Melville's Bartleby (1990 [1853]) is an interesting figure because he is the "enemy of the law" par excellence. Bartleby's straightforward rejection of necessity, his "I prefer not to," as it is embodied in the commands and requests of his employer, the Man of the Law, cannot be contested within the very terms of necessity that he is rejecting. "Bartleby is employed, so he must work," speaks the ideology of contractual obligation. When he does not work, justifications that comport with the law of obligation must be found if he is to remain an employee. The Man of the Law is thus a "man of the law" insofar as he seeks at each moment the necessary obligation with which Bartleby is complying.[29] Given Bartleby's structurally subordinate position as an employee, there must be some sort of intelligible reason why he remains employed yet refuses to work.

But Bartleby is not bound by the logics of the Man of the Law, logics that would construe Bartleby as some sort of work-dependent homo sacer. Instead, Bartleby constitutes himself as sovereign by deciding on the exception. He operates according to a discursive logic totally unintelligible to the Man of the Law. Bartleby and the Man of the Law may share the same bio-material space, but it is in no way clear that the "things that represent only themselves" are identical for both of them. Bartleby the indolent, Bartleby the indigent, this Bartleby is sovereign, even as he appears from without to be bare life. The man of the law, who works that he may be secure in himself, presumes necessity where none exists. He must act as he does lest he be consigned to a worse fate. The Man of the Law would surrender mastery over his small domain were he to act as Bartleby does. Little does the Man of the Law know that Bartleby's form of mastery is freer than his own because Bartleby does not hide behind the veil of necessity. Bartleby belongs solely to himself: always vulnerable, ontologically precarious, at each moment the source of his own self-authorship in the world. But if Bartleby's life remains ontologically insecure even as Bartleby act for himself, then the pacifying figure of the declared homo sacer can no longer perform its palliative function. It has only ever served as a fiction.

Instead of seeking out how and where life has, from the perspective of dominant ideological and discursive regimes, been made ontologically bare, we must instead come to terms with how life is lived, how subjects act according to the laws they give themselves, and how their capacities to act in accordance with their own modes of existence actively, and sovereignly, produce the world as they experience it. This is sovereignty from the perspective of Bartleby and his kin, who appear as unnecessary excesses within the logics of bourgeois, neoliberal, biopolitical ideologies. It is precisely this space that cannot be accounted for, or which can only be accounted for as a space of the disallowed, pathological, always-already bare, that grounds all possibility of reconstruing the nomos of the present regime.

\section{Endnotes}

1. Schmitt makes this link evident when he writes, "The exception in jurisprudence is analogous to the miracle in theology" (2005 [1922]: 36). This element of Schmitt's thought is also central to Bonnie Honig's reading of him in relation to Jewish theologian Franz Rosenzweig: "I add to that [i.e., the possibility of a "secret conversation" between Schmitt and Walter Benjamin] the possibility of another such secret conversation, between Schmitt and Rosenzweig, in which neither side acknowledged the other and the stakes were also high. When we put Schmitt into dialogue with Rosenzweig on the topic of the miracle, we switch our gaze from sovereign to 
popular power or to sovereignty as implicated in and dependent upon popular power" (2009: 89).

2. For both forms of power, the word potestas corresponds in some accounts to potential, a term that will become important for my purposes. See Elshtain 2008: 38-39, as well as Agamben 1999 [1993]: 254.

3. I draw the distinction between "precariousness" as an ontologically shared quality of all existent entities and "precarity" as the socially distributed conditions that engender life or suppress it from Judith Butler in Frames of War: When Is Life Grievable? (2010 [2009]: 2-3).

4. This is a creation of zoē in the sense that the ties of community are juridically withdrawn from homo sacer. To the extent that Agamben typically seems to equate the juridical with life, withdrawing the protections of the juridical is thus by definition what creates bare life.

5. It could be objected that my use of topological/ topographical language is inappropriate when describing the sovereign-homo sacer relationship and can only be applied to spaces of exception. Any concrete relationship between these figures must take place materially, which thusly produces space, i.e., a topography. It is therefore justifiable to think of the abstract, ideal relationship as topological. Indeed, much of this article is devoted to emphasizing the spatial (and thus topological) quality of ideation.

6. Agamben's response, as I understand him, would likely be something along the lines of, "But killing the sovereign does not constitute him as homo sacer. It constitutes him as dead. Homo sacer is a form of life, one that is not bios because the law that creates social life does not hold for it. The Sovereign, on the other hand, is covered by the law, even when he has suspended its normal operation."

What makes homo sacer a distinct form of life, though, is its proximity to a power that expresses itself ultimately in killing. It is not the ban alone that makes homo sacer but homo sacer's perpetual proximity to death. Even without the law's protections, ethical forms of communal life are still possible. Indeed, they are what make the law possible. Homo sacer only exists to the extent that it might be killed. This possibility, this virtuality, obtains for the Sovereign as for any other. We see this clearly in the transition from the state of nature into society because the figure that becomes sovereign had just (concretely) been homo sacer precisely because it existed in relation to other homines sacri/sovereigns as a figure that could be killed, though not necessarily killed without recompense. The Sovereign may still be killed, meaning that the shift from state of nature to the juridical order is purely topographical.

An alternative, far cruder way of putting this point is that Agamben's study ends by discovering the presumptions with which Foucault's account of biopolitics begins: with power immanent at every moment to its own exercise.

7. Agamben's reading finds some basis in Foucault's account of biopolitics and biopower. For example, Foucault writes, "If one can apply the term bio-history to the pressures through which the movements of life and the processes of history interfere with one another, one would have to speak of bio-power to designate what brought life and its mechanisms into the realm of explicit calculations and made knowledge-power an agent of transformation of human life. It is not that life has been totally integrated into techniques that govern and administer it; it constantly escapes them. ... But what might be called a society's 'threshold of modernity' has been reached when the life of the species is wagered on its own political strategies. ... $[\mathrm{M}]$ odern man is an animal whose politics places his existence as a living being in question" (1990 [1976]: 143).

Foucault clarifies this point a bit in his lecture series of 1976, "Society Must Be Defended": "This excess of biopower appears when it becomes technologically and politically possible for man not only to manage life but to make it proliferate, to create living matter, to build the monster, and, ultimately, to build viruses that cannot be controlled and that are universally destructive. This formidable extension of biopower, unlike what I was just saying about atomic power, will put it beyond all human sovereignty" (2003 [1997]: 254).

There is a whole school of literature since Foucault that has taken as its object exactly these mechanisms of the multiplication of and intervention into the vital processes of life-formation. As Maurizio Lazzarato puts it in a short essay, "The patenting of the human genome and the development of artificial intelligence; biotechnology and the harnessing of life's forces for work, trace a new cartography of biopowers. These strategies put in question the forms of life itself" (2002: 100). Agamben touches on some of these specific strategies at the end of Homo Sacer when he references "the body of Karen Quinlan or the overcomatose person" for whom "biological life which the machines are keeping functional by artificial respiration, pumping blood into the arteries, and regulating the blood temperature - has been entirely separated from the form of life that bore the name Karen Quinlan: her life becomes (or at least seems to become) pure zoē" (1998 [1995]: 186). Here "life" and "form of life" are separated through technologies that multiply life in an unrecognizable form.

My focus in this paper is less on "biopower" in the sense of the techniques of control that take life and the body as their direct object of study, control, regulation, and multiplication but instead on "biopolitics" as the structural distribution of precarity and potential vitality. This structural distribution of life and death is, of course, always carried out in relation to the forms of biopower historically present in a given society. The way that the health of a body is conceptualized is, as Foucault demonstrates through his discussion of the bourgeois body, the basis for understanding how the health of a body politic can also be maintained. Bodies 
that cannot be kept healthy or that cannot be made to accord with the optimizable imago of health present a pathological threat to the society as a whole, which is the sense in which the "society must be defended" against itself.

When this "secret" or "coded war" takes the form of a medicalized attempt to multiply life for society as a whole, then the logics of distribution is "racist" in some sense. Indeed, to have a minority element of the body politic that can be cast as inherently deviant or pathological and thus either be exterminated through genocide or slowly and gradually be deprived the necessities of life while also being blamed for its inability to flourish is a convenient technique of biopower present in contemporary capitalist societies. Migrants, welfare recipients, criminals, refugees, and so forth are forms of life imaginatively incompatible with the body politic's health. Migration must consequently have ceased and deportation increased; welfare must be restricted, stopped, or put under draconian work or drug testing requirements; criminals must be stripped of their rights, denied employment, and permanently disparaged; and refugees must be denied both aid and asylum.

While Lazzarato calls for a focus on the medical and scientific technologies that modify life, and while other have taken him up in the study thereof (Braun 2007; Dillon and Lobo-Guerrero 2008; Rose 2001), it seems to me that the most important mechanisms operative today when considering the biopolitical quality of contemporary society are not those of medicalized intervention in the form of a "molecular politics" but instead of distributional regimes that operate in a similar manner to the more directly scientific racisms analyzed by Foucault but without as direct a connection to genetic bases for the distributive determinations. Instead, factors such as educational performance, preparedness for the workforce, and criminal history function to justify providing resources to some and denying them to others. This is arguably why Foucault turned to markets rather than medicine as he sought to trace the development of biopolitical logics. To the extent that such distributional regimes map onto the same hierarchies that colonial and scientific racism helped to develop is more a matter of historical contingency than logical necessity, even as the symbolic relationships that are made regular have political effects that go beyond what is logically defensible within the veridical regime that focuses on "social pathologies." We shall explore this topic in greater sociological depth below in the context of U.S. anti-black racism, which feeds off prior logics rooted in scientific racism but largely displaces those logics into alternative regimes of distributional decision-making.

8. If one reads this chapter after spending too much time reading Agamben, it is difficult not to be struck by the first paragraph, in which Foucault basically anticipates in advance every argument Agamben will raise, from a discussion of the Roman roots of the "power over life and death," to an active acknowledgment that sovereignty as a form of power had of course been concerned with life and could even expose it to death, to delinking "the decision" (in this case, the decision to wage war) from this exposure (Foucault 1990 [1976]): $135,137)$. Perhaps it was a tacit response to Schmitt, or at least the line of Schmittian thinking that Agamben eventually picks up.

9. This study is in some sense continued by Wendy Brown in Undoing the Demos: Neoliberalism's Stealth Revolution (2015), though she does not primarily use the language of biopolitics to do so.

10. Agamben's concluding few pages in Homo Sacer do move away from an exclusive focus on the logics of sovereignty to consider how biopolitics play out historically. This far more interesting account is picked up and developed in Remnants of Auschwitz: The Witness and the Archive (2002 [1998]), which captures the biopolitical moment that seems to elude Agamben throughout Homo Sacer.

11. Sergei Prozorov's Foucault, Freedom, and Sovereignty (2007) has been highly influential to my thinking in these matters and is one of the more interesting readings of both Foucault and Agamben that I have encountered.

12. This phrasing borrows from Italo Calvino's short story "A Sign in Space," included in Cosmicomics (1968 [1965]), in which Calvino explores the origin of signs, and thus also of space and thought. He touches simultaneously on the logics of simulation, genealogy, sovereignty, authorship, signification, and spatiology. For example:

"I went on looking, and signs kept growing thicker in space; from all the worlds anybody who had an opportunity invariably left his mark in space somehow; and our world, too, every time I turned, I found more crowded, so that world and space seemed the mirror of each other, both minutely adorned with hieroglyphics and ideograms, each of which might be a sign and might not be: a calcareous concretion on basalt, a crest raised by the wind on the clotted sand of the desert, the arrangement of the eyes in a peacock's tail (gradually, living among signs had led us to see signs in countless things that, before, were there, marking nothing but their own presence; they had been transformed into the sign of themselves and had been added to the series of signs made on purpose by those who meant to make a sign), the fire-streaks against a wall of schistose rock, the four-hundred-and-twenty-seventh groove slightly crooked - of the cornice of a tomb's pediment, a sequence of streaks on a video during a thunderstorm (the series of signs was multiplied in the series of the signs of signs, of signs repeated countless times always the same and always somehow different because to the purposely made sign you had to add the sign that had happened there by chance), the badly inked tail of the letter $\mathrm{R}$ in an evening newspaper joined to a thready imperfection in the paper, one among the eight hundred thousand flakings of a tarred wall in the Melbourne docks, the curve of a graph, a skid-mark on 
the asphalt, a chromosome ...

In the universe now there was no longer a container and a thing contained, but only a general thickness of signs superimposed and coagulated, occupying the whole volume of space; it was constantly being dotted, minutely, a network of lines and scratches and reliefs and engravings; the universe was scrawled over on all sides, along all its dimensions. There was no longer any way to establish a point of reference: the Galaxy went on turning and I could no longer count the revolutions, any point could be the point of departure, any sign heaped up with the others could be mine, but discovering it would have served no purpose, because it was clear that, independent of signs, space didn't exist and perhaps had never existed" (Ibid: 38-39).

13. Caraccioli is concerned with the ways that international relations theories of space have ignored the body as a lived site and instead replaced it with formal abstractions that serve as the template for a resulting international order. Rather than seeing the fiction of the international system as a necessity, "The phenomenology of the body teaches us that the meaning of inter-national space is determined by who is writing its narratives, constituting global practices and identities through the embodied and local circumstances we all share" (2011: 100).

14. In his search for the secret, hidden heart of sovereignty, Agamben's study in Homo Sacer opposes the apparent to the actual and participates in the dualist ontology Nietzsche deconstructs.

15. "[P]ain is the most powerful aid to mnemonics" (Nietzsche 1989 [1887]: 61 [II.3]).

16. Lefebvre argues that the representation that transforms these intersecting flows into a singular and unified object also tends to reify the social being of the humans who inhabit it. Thus, a "critique of space" is required to reveal the material relations in which humans as social beings are embedded.

Another fruitful take on the role that social life plays in constituting perception can be found in William Connolly's essay "The Vicissitudes of Experience," in which he reads "Merleau-Ponty, Michel Foucault, and Gilles Deleuze into conversation with each other and with recent work in neuroscience" (Connolly 2011: 43). Connolly emphasizes that even perception is, for the most part, not an inbuilt feature of human experience but rather the effect of how we are socialized into perceiving. This chapter precedes his analysis of fascist bodily performativities in Aspirational Fascism by roughly six years but is clearly in a related space of analysis.

17. " $[\mathrm{I}]$ ndividuals are always-already interpellated by ideology as subjects, which necessarily leads us to one last proposition: individuals are always-already subjects. Hence individuals are 'abstract' with respect to the subjects, which they always-already are” (Althusser 2001
[1970]: 119).

18. I am not generally a regular listener of This American Life. However, their show, as well as in-depth journalism more generally, is an excellent source for real-world experiences that inhabit the crucial political spaces with which political theory ought to concern itself. Political theory is itself "dead and undialectical," to borrow a Foucauldian phrasing, to the extent that it is not concerned with actual political struggle. This comment may seem out of place given the abstract character of the analysis that has preceded this point. But for all its abstractions, I am at least convinced that there are real political implications of diagnosing the relationship between the lived-conceivedperceived triad of space as well as the movement from appropriation to distribution to production.

19. I have explored these spatial practices through a close reading of a This American Life podcast in "Sovereignty in the City: The Tacticalization of 'Disallowed' Life" (2017).

20. Again, "city" is an incredibly broad concept encompassing a variety of spatial milieus. Thus, to speak of the "spatial distribution of U.S. cities" is to risk overgeneralization in potentially problematic ways. The concept of nomos is helpful in this regard, as we shall see.

21. At the very least, a third form of residency could be added to this list: immobile nomadism. In a series of interviews in the late 1990s and early 2000s, Daniel Kerr (2016) delved into the daily life patterns of "unhoused" persons in Cleveland, Ohio. Interview subjects described a sense of immobility that increasingly constrained them as the variety of cheap housing and well-paying short-term employment options disappeared. At the same time, the interview subjects often had to walk miles and miles each day to travel from a place to sleep to a place to work to a place to eat.

A migratory life masters space as much as any other series of spatial practices, but in the instances Kerr documents, this way of life clearly takes place within rather than contesting the dominant mode of land appropriation. It is certainly worlds, not to mention millennia, apart from the nomads described by James Scott (2017), who would also move about to find food yet who, according to the available evidence, seemed to live lives of comparative abundance when contrasted with unhoused Clevelanders. Even this ancient migratory spatial appropriation may have constituted something like a nomos.

22. Marcuse, writing in the 1990 s, was seeking to account for ghettos that were "new" as of the several decades prior, so in that sense, the spatial formation may indeed have been novel. Even if not, his typology is still broadly helpful for thinking through how space and material possibilities are distributed. 
23. To clarify against one potential misreading of the preceding, the argument is not that all (or even most) impoverished residents of urban spaces are black, nor is it to argue that most black people are residents of impoverished urban spaces. Rather, the argument is that race has become symbolically identified with a particular space, and this symbolical identification continues to have concrete effects in how space is appropriated and distributed.

24. This article is listed in the book in which it is included as having been adapted from the previous one by Anderson, though there is little noticeable similarity between the two.

25. This may be the reason that Foucault's "Society Must Be Defended" begins with the emergence of race and ends with biopolitics. For example, he states the following in his final lecture of that series: "It is, I think, at this point [the point where a regime of power justified by the preservation of life can take action to kill] that racism intervenes. I am certainly not saying that racism was invented at this time. It had already been inexistence for a very long time. But I think it functioned elsewhere. It is indeed the emergence of this biopower that inscribes it in the mechanisms of the State. It is at this moment that racism is inscribed as the basic mechanism of power, as it is exercised in modern States. As a result, the modern State can scarcely function without becoming involved with racism at some point, within certain limits and subject to certain conditions" (2003 [1997]: 254, emphasis mine).

26. This phrasing is from Timothy Luke (Spring 1993: 254-255), who is commenting on the implications of dialogicality in the context of realist beliefs in the international system of states, as well as in a world in which states function as the basic model of international activity: "Writing is reading. Reading is writing. The unraveling of the state today, or the loosening of its jurisdiction(s), echoes the cacophony of new coding games made articulate by modernization's encirclement of nature and globalization of exchange since 1945 . New social forces beyond the state, such as the market, science, the intelligentsia, technology, the mas consuming/producing public, medicine, or even global ecology, find alternative institutional agencies that allow them to write over/against/for and speak to/against/for the state. ... New dictions are fabricating their own codes of power, spaces of operation, frames of time, and signs of authority in the many currents of the global flow."

See also Patchen Markell (2003: 119-120): "On my reading, the crucial connection between the pursuit of recognition and social subordination lies in the fact that the pursuit of recognition involves a failure of acknowledgment of one of the basic circumstances of human action - the fact that action is always, ultimately, interaction, and that this interaction introduces an ineliminable contingency into life among others. This circumstance is, in a certain respect, a limitation on our agency, at least as long as agency is understood in terms of sovereignty [or in terms of its correspondence to the formal concept of sovereignty] - but it is also the enabling condition of agency and freedom themselves."

27. Because one is choosing specific attachments, this is clearly not a Kantian sense of self-legislation.

28. Schmitt would perhaps take this to be a misuse of the term because it is focused on distribution, which is only made possible by appropriation. Further, as discussed above, Schmitt distinguishes that not every new appropriation inaugurates a new nomos. The implications of Schmitt's analysis of nomos and its derivation from nemein would seem to indicate that every spatial order, at whatever scale, has a nomos, a way of dividing the space in use, that can be discerned. So even as he states that "for us, nomos is a matter of the fundamental process of apportioning space that is essential to every historical epoch - a matter of the structure-determining convergence of order and orientation in the cohabitation of peoples on this now scientifically surveyed planet," the sense in which I use it here is closer to the "nomos by which a tribe, a retinue, or a people becomes settled, i.e., by which it becomes historically situated and turns a part of the earth's surface into the force-field of a particular order, becomes visible in the appropriation of land and in the founding of a city or a colony" (2006 [1950]: 78, 70).

29. Giorgio Agamben makes essentially this same point in his reading of Bartleby by noting that the Man of the Law turns to books about the (un)freedom of the will in order to comprehend Bartleby's rejection of his simple orders (1999 [1993]: 254). Agamben's essay is fascinating and is largely why I have turned my attention to Bartleby in the first place. However, Agamben reads Bartleby somewhat narrowly as a paragon of potentiality rather than a being that is at each moment actualized. What Bartleby offers to us is not a lesson about potentiality but about resistance as well as its potentially nihilistic tendencies. It is no accident that Bartleby, by refusing to eat, comes closer to withering away than actively to dying. 


\section{References}

Agamben, Giorgio. 1999 [1993]. "Bartleby, or On Contingency." Pp. 243-271 in Potentialities: Collected Essays in Philosophy. Trans. Daniel Heller-Roazen. Stanford, CA: Stanford UP.

. 1998 [1995]. Homo Sacer: Sovereign Power and Bare Life. Trans. Daniel Heller-Roazen. Stanford, CA: Stanford UP.

2002 [1998]. Remnants of Auschwitz: The Witness and the Archive. New York: Zone Books.

Althusser, Louis. 2001 [1970]. "Ideology and Ideological State Apparatuses: Notes towards an Investigation." Pp. 85-126 in Lenin and Philosophy, and other essays. New York: Monthly Review.

Anderson, Elijah. 2012a. “The Iconic Ghetto." The Annals of the American Academy of Political and Social Science. Vol. 642 (July): 8-24.

. 2012b. “Toward Knowing the Iconic Ghetto." Pp. 67-82 in The Ghetto: Contemporary Global Issues and Controversies. Eds. Ray Hutchinson and Bruce D. Haynes. Boulder, CO: Westview.

Braun, Bruce. 2007. "Biopolitics and the Molecularization of Life." Cultural Geographies. Vol. 14.1: 6-28.

Brown, Wendy. 2015. Undoing the Demos: Neoliberalism's Stealth Revolution. Brooklyn, New York: Zone Books.

Butler, Judith.2010 [2009]. Frames of War: When Is Life Grievable? Paperback edition. New York: Verso.

2006 [1990/1999]. Gender Trouble: Feminism and the Subversion of Identity. New York: Routledge.

Calvino, Italo. 1968 [1965]. “A Sign in Space.” Pp. 31-39 in Cosmicomics. Trans. William Weaver. New York: Harcourt.

Caraccioli, Mauro J. 2011. "Spatial Structures and the Phenomenology of Inter-National Identity." International Political Sociology. Vol. 5.1: 98-101.

Carion, Christian. 2005. Joyeux Noël. Performers Diane Kruger, Benno Fürmann, and Guillaume Canet. Nord-Ouest Productions and Senator Film Produktion.

Connolly, William E. 2010. A World of Becoming. Durham, NC: Duke UP.

2017. Aspirational Fascism: The Struggle for Multifaceted Democracy under Trumpism. Minneapolis, MN: Minnesota UP.

2007. "The Complexities of Sovereignty." Pp. 23-42 in Giorgio Agamben: Sovereignty and Life. Eds. Matthew Calarco and Steven DeCaroli. Stanford, CA: Stanford UP.

Debrix, François. 2015. "Topologies of Vulnerability and the Proliferation of Camp Life." Environmental and Planning D: Society and Space. Vol. 33.3 (June): 444-459.
Dillon, Michael, and Luis Lobo-Guerrero. 2008. "Biopolitics of Security in the 21st Century: An Introduction." Review of International Studies. Vol. 34.2 (Apr.): 265-292.

Dvorak, Petula. April 4, 2018. “The Woman Who Got Fired for Flipping off President Trump Just Sued Her Former Employer." The Washington Post. Accessed online April 5, 2018. https://www.washingtonpost.com/local/the-womanwho-got-fired-for-flipping-off-president-trump-just-sued-herformer-employer/2018/04/04/64c7376c-3840-11e8-acd535eac230e514_story.html?utm_term $=$. b5 fa9245ed5c.

Elshtain, Jean Bethke. 2008. Sovereignty: God, State, and Self. New York: Basic Books.

Foucault, Michel. 2008 [2004]. The Birth of Biopolitics: Lectures at the Collège de France, 1978-1979. Ed. Michel Senellart. Trans. Graham Burchell. New York: Picador.

. 1990 [1976]. The History of Sexuality, Volume 1: An Introduction (The Will to Knowledge). Trans. Robert Hurley. New York: Vintage Book.

2003 [1997]. "Society Must Be Defended": Lectures at the Collège de France, 1975-1976. Eds. Mauro Bertani and Alessandro Fontana. Trans. David Macey. New York: Picador.

Friedmann, John, and Goetz Wolff. 1982. "World City Formation: An Agenda for Research and Action." International Journal of Urban and Regional Research. Vol. 6.3 (September): 309-344.

Friedmann, John. 1986. "The World City Hypothesis." Development and Change. Vol. 17: 69-83.

Glass, Ira. March 16, 2018. "641: The Walls.” This American Life. Chicago Public Media. Accessed online April 5, 2018. < https://www.thisamericanlife.org/641/the-walls.>

Hobbes, Thomas. 1968 [1651]. Leviathan. New York: Penguin.

Honig, Bonnie. 2009. Emergency Politics: Paradox, Law, Democracy. Princeton, NJ: Princeton UP.

Kerr, Daniel R. 2016. “Almost Like I Am in Jail': Homelessness and the Sense of Immobility in Cleveland, Ohio." Cultural Studies. Vol. 30.3: 401-420.

Kolakowski, Leszek. 1981 [1976]. Main Currents of Marxism: The Founders (vol. 1). Trans. P. S. Falla. New York: Oxford UP.

Lazzarato, Maurizio. 2002. "From Bipower to Biopolitics." Pli: The Warwick Journal of Philosophy. Vol. 13: 99-112.

Lefebvre, Henri. 1991 [1974]. The Production of Space. Trans. Donald Nicholson-Smith. Cambridge, MA: Basil Blackwell.

Luke, Timothy W. 1993. "Discourses of Disintegration, Texts of Transformation: Re-Reading Realism in the New World 
Order." Alternatives: Global, Local, Political. Vol 18.2 (Spring): 229-258.

Marcuse, Peter. 2012. "De-spatialization and Dilution of the Ghetto: Current Trends in the United States." Pp. 33-66 in The Ghetto: Contemporary Global Issues and Controversies. Eds. Ray Hutchinson and Bruce D. Haynes. Boulder, CO: Westview.

1997. "The Enclave, the Citadel, and the Ghetto: What Has Changed in the Post-Fordist U.S. City," Urban Affairs Review. Vol. 33.2 (November): 228-264.

Markell, Patchen. 2003. Bound by Recognition. Princeton, NJ: Princeton UP.

Marx, Karl. 1977 [1867/1873]. Capital, Volume One. Trans. Ben Fowkes. New York: Vintage Book.

McTeigue, James. 2005. V for Vendetta. Performers Hugo Weaving, Natalie Portman, and Rupert Graves. Warner Bros. and Virtual Studios.

Melville, Herman. 1990 [1853]. "Bartleby, the Scrivener: A Story of Wall Street." Pp. 3-34 in Bartleby and Benito Cereno. New York: Dover Publications.

Minca, Claudio. 2006. "Giorgio Agamben and the New Biopolitical Nomos." Geografiska Annaler: Series B, Human Geography. Vol. 88.4: 387-403.

Nietzsche, Friedrich. 1966 [1886]. Beyond Good and Evil: Prelude to a Philosophy of the Future. Trans. Walter Kaufmann. New York: Random House.

1989 [1887]. On the Genealogy of Morals. Trans. Walter Kaufmann. New York: Vintage Books.

Prozorov, Sergei. 2007. Foucault, Freedom, and Sovereignty. Burlington, VT: Ashgate Publishing.

Rogers, Peter. 2016 [2012]. Resilience and the City: Change, (Dis) Order and Disaster. New York: Routledge.
Rose, Nikolas. 2001. “The Politics of Life Itself." Theory, Culture, \& Society. Vol. 18.6: 1-30.

Sassen, Saskia. 2000. Cities in a World Economy. Second Edition. Thousand Oaks, CA: Pine Forge.

. 2016. "The Global City: Enabling Economic Intermediation and Bearing Its Costs." City \& Community. Vol 15.2 (June): 97-108.

Schmitt, Carl. 2006 [1950]. The Nomos of the Earth. Trans. G. L. Ulmen. New York: Telos Press.

2005 [1922]. Political Theology: Four Chapters on the Concept of Sovereignty. Trans. George Schwab. Chicago: University of Chicago Press.

Scott, James C. 2017. Against the Grain: A Deep History of the Earliest States. New Haven, CT: Yale UP.

Semuel, Alana. March 28, 2018. "Chicago's Awful Divide." The Atlantic. Accessed online April 6, 2018. https:// www.theatlantic.com/business/archive/2018/03/ chicago-segregation-poverty/556649/.

Smithsimon, Gregory. 2010. "Inside the Empire: Ethnography of a Global Citadel in New York." Urban Studies. Vol. 47.4 (April): 699-724.

Taylor, Benjamin B. 2017. "Sovereignty in the City: The Tacticalization of 'Disallowed' Life." SPECTRA. Vol. 6.1 (Sept.). DOI: http://doi.org/10.21061/spectra.v6i1.402.

Wacquant, Loïc. 2012. "A Janus-Faced Institution of Ethnoracial Closure: A Sociological Specification of the Ghetto." Pp. 1-31 in The Ghetto: Contemporary Global Issues and Controversies. Eds. Ray Hutchinson and Bruce D. Haynes. Boulder, CO: Westview. 